\title{
Gender inequity in Saudi Arabia and its role in public health
}

\author{
A.E.H. Mobaraki and B. Söderfeldt ${ }^{2}$
}

$$
\text { عدم الله حسين مُباركي، بيورن الجنسين في السعوديرة وفلت وتأثيره على الصحة العمومية }
$$

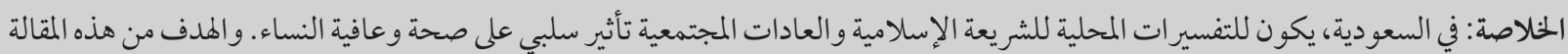

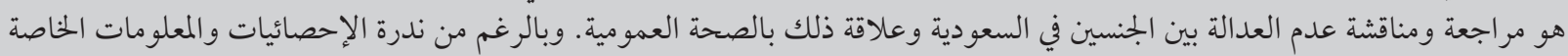

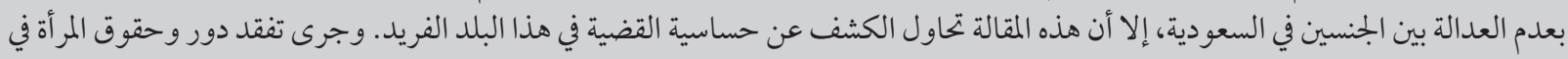

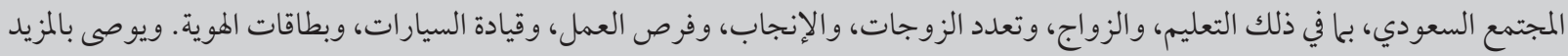

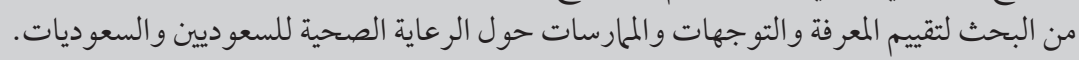

ABSTRACT In Saudi Arabia, local interpretations of Islamic laws and social norms have a negative impact on the health and well-being of women. The objective of this literature review was to discuss gender inequity in Saudi Arabia and its relation to public health. Despite the scarcity of recent statistics and information regarding gender inequity in Saudi Arabia, this review is an attempt to explore this sensitive issue in this country. Women's roles and rights in Saudi society were examined, including education, marriage, polygamy, fertility, job opportunities, car driving and identification cards. Further research to assess knowledge, attitudes and practices towards health care of Saudi men and women is recommended.

\section{L'inégalité entre hommes et femmes en Arabie saoudite et ses conséquences sur la santé publique}

RÉSUMÉ En Arabie saoudite, les interprétations locales des lois islamiques et des normes sociales ont des effets négatifs sur la santé et le bien-être des femmes. L'objectif de cette revue de la littérature était d'étudier l'inégalité entre hommes et femmes en Arabie saoudite et le rapport de cette dernière avec la santé publique. Malgré la rareté des statistiques et des informations récentes sur ce sujet dans le pays, notre revue tente d'explorer cette question sensible. Nous avons examiné le rôle et les droits de la femme dans la société saoudienne, notamment sous l'angle de l'éducation, du mariage, de la polygamie, de la fertilité, des possibilités d'emploi, de la conduite automobile et des documents d'identité. Nous recommandons de poursuivre le travail de recherche afin d'évaluer les connaissances, les attitudes et les pratiques en matière de soins de santé des hommes et des femmes saoudiens. 


\section{Introduction}

Inequity based on gender exists to a varying extent in all societies and varies over time and across social and ethnic groups [1]. Within every community, nationality and class, the burden of hardship often falls disproportionately on women [2-4]. "Inequality" and "inequity" are different concepts; the former applies to any variation, while the latter applies to both avoidable and unjust causes [5]. There are many different kinds of gender inequity in, for example, mortality rates, natality rates, basic facilities such as schooling, special opportunities for training, professional aspects such as employment, ownership of property and land, and household duties [6]. Gender inequity is usually translated into a power imbalance with women being more vulnerable. This vulnerability is more precarious in traditional patriarchal societies.

Saudi Arabia has a population estimated to be about 23 million in 2006 including $27.1 \%$ foreigners [7]. Of the Saudi citizens, 90\% are Arabs and all are Muslims. Annual per capita income is about US\$ 13600 [8]. The system of government in Saudi Arabia is a monarchy, with the constitution governed by a strict interpretation of Islamic law [9]. The Council of Ministers is nominated by the King. The media (print and visual) are government owned. Policies are formulated and implemented by the government. There are no people's representatives or independent interest groups to represent health concerns to the government. The government ran municipal elections for the first time in 2005, although women were not allowed to vote [8].

In this unique country, local interpretations of Islamic laws and social norms can have a negative impact on the health and well-being of women. The objective of this literature review was to discuss gender inequity in Saudi Arabia and its relation to public health. Women's roles and rights in Saudi society were examined, including education, marriage, polygamy, fertility, job opportunities, car driving and identification cards.

\section{Methods}

The PubMed online database and the Google search engine were used for the literature review. The inclusion criteria were based on scope, content, accuracy, authority, currency, purpose, workability, searching, connectivity and cost of the chosen journals and web-based information [10]. Most of the sources were articles in peer-reviewed journals, websites of reputable organizations and national official websites. The WHOIS tool was used to check the ownership of the domain names.

A PubMed database search were made using the phrases "gender inequity", "Saudi women" and "Muslim women". The search was limited to English language articles and the period from 1985 to the present. A Google search was made for "Saudi women health" and out of 16000 hits, the top 50 items were scanned. Related books were accessed through the general library at the University of Lund, Sweden. The Islamic holy book, the Quran, was an important source for this review. To draw some comparisons with a European country, a Google search for "Swedish health" found 99900 hits and the top 150 items were scanned. Unpublished data, predominantly theses, were searched at the University of Lund, Sweden, the University of Leeds, United Kingdom, and the University of Gunma, Japan, but no relevant information was found.

\section{Health care in Saudi Arabia}

The health care system in Saudi Arabia is mostly owned and handled by the Ministry of Health $(\mathrm{MOH})$, and health care expenditure accounted for
$5.9 \%$ of the 2006 government budget. The $\mathrm{MOH}$ goal is to provide universal free medical care for Saudi citizens and also for the millions of international pilgrims undertaking the hajj to the holy city of Mecca. The $\mathrm{MOH}$ is supported directly by the government and has good infrastructures and administrative structures. About $60 \%$ of health services are provided by the $\mathrm{MOH}$ and $18 \%$ by other government hospitals such as universities and military hospitals which are open to the public. In the last decade more private hospitals have been established, financed by some medical companies and by selfpayment. These private hospitals cover the remaining $22 \%$ of health services which are monitored by the $\mathrm{MOH}[7]$. Due to the rapid increase in the population, the government has planned to adopt a health insurance policy [11] to reduce its financial burden and to improve health standards [12].

In 2006, the ratio of doctors in Saudi Arabia was 20 and of dentists was 2.14 per 10000 inhabitants [7]. In comparison, the ratios of doctors and dentists in Sweden in 2003 were about 44.4 and 15.6 per 10000 inhabitants respectively [13]. The infant mortality rate in Saudi Arabia was high in the early 1980s, with an estimated 118 deaths per 1000 live births [14]. By contrast, based only on deliveries of infants in hospitals of the $\mathrm{MOH}$, the infant mortality rate was 18.6 per 1000 in 2006 [15]. Despite the dramatic progress in health care in the last 3 decades, the high birth rate [7] and other factors have left Saudi Arabia a country where only $70 \%$ of females are literate [8] and the child mortality rate was 20 per 1000 children in 2006 [7]. In comparison, Sweden had an estimated child mortality rate of 4 per 1000 children in 2005 [16]. 


\section{Women's education}

Although at present there are more female graduates than males in Saudi Arabia [9], statistics reveal that about $30 \%$ of Saudi women are still illiterate [8]. This might be because opening schools for girls initially met with strong opposition in some parts of Saudi Arabia, where nonreligious education was regarded as unsuitable for girls [17]. Moreover, coeducation is not allowed and the curriculum in girls' schools has long been a less comprehensive version of that taught in boy's school [9].

There is no sports education in girls' school and it is prohibited by social norms for females to practise physical activities in public. Lack of exercise is a known cause of obesity. It is not surprising therefore that the prevalence of obesity (body mass index $>30$ $\left.\mathrm{kg} / \mathrm{m}^{2}\right)$ for 30-70-year-old Saudi females was $44.0 \%$ compared with only $26.4 \%$ in males [18]. In comparison the prevalence of obesity for 25-64-yearold Swedes was $11.0 \%$ for females and $14.8 \%$ for males [19].

Saudi women cannot study engineering, law or journalism. According to the latest official figures, $49.9 \%$ of the Saudi population are female [7] and barely $21 \%$ of them contribute to the social development, because it is socially unacceptable for women to work in fields other than teaching and medicine [9].

Even though Saudi Arabian women work in the medical field and have achieved good success at junior levels, they are exposed to some degree of discrimination at higher levels [20]. Furthermore, due to contact with male medical staff and patients and night shift-work, medical employment for women is not always welcomed by Saudi society and may be an obstacle to future marriage for a woman. This could explain the low level of satisfaction among Saudi female nurses [21].

\section{Marriage}

In Saudi Arabian personal status law an unmarried adult woman is the ward of her father, a married woman is the ward of her husband and a widowed woman is the ward of her sons. In a maledominated and tribal community with a high social coherence, it is not unusual for a woman to be forced to marry a relative. More than $50 \%$ of marriages in Saudi Arabia are consanguineous [22]. The infant mortality rate is high (18.5 per 1000 in 2006) despite good health care facilities and an effective vaccination programme, and genetic diseases are probably a contributory factor [17]. Roughly 1.5 million Saudi Arabians suffer from or are carriers of inherited blood diseases and this constitutes a heavy burden to families and the nation. For instance, in a single region the prevalence of beta-thalassaemia trait alone was found to be $3.4 \%$ [23].

The law affects women's health care at many levels. There is a $\mathrm{MOH}$ law preventing a woman being admitted to a government hospital unless she is accompanied by her male guardian [24]. Furthermore, especially in rural areas, a male relative may prevent a woman being treated by a male gynaecologist or obstetrician even in an emergency. An adult woman cannot herself sign the consent for an invasive medical procedure which might be urgently required [25].

Due to the fact that there is no legal minimum age for marriage in Saudi Arabian society, females can be forced by tradition to marry under the age of 16 years [26]. Early teenage marriage was found in $27.2 \%$ of Saudi Arabian women. Most of these were illiterate (57.1\%), housewives (92.4\%) and grand multiparae $(66.7 \%)$ [27]. Thus teenage pregnancy may be a factor behind the high maternity mortality rate of 12 per 100000 live births in 2006 [7]. In contrast, Sweden had a maternal death rate of 2.4 per 100000 live births during 1991-93 [28].
Abortion is forbidden according to the Saudi Arabian interpretation of Islamic law and is only allowed when a medical committee decides there is a risk to the mother if she continues her pregnancy [22]. Therefore, although genetic haematological disease is common due to consanguineous marriages, antenatal screening programmes for incurable genetic diseases have no practical use. Consequently primary prevention programmes such as premarital genetic screening tests are the only option [23]. A study has shown that a majority of Saudi Arabian mothers were unaware of the increased risks of haemoglobinopathies from consanguinity. However, the women accepted the general idea of prenatal screening with the option of abortion, presumably because most of the burden and stress of taking care of a child with a genetic disease falls on the woman [29].

An additional burden on Saudi Arabian women is the high fertility rate. It has led to a high prevalence of low bone density and osteoporosis among postmenopausal Saudi Arabian women and its complications, such as bone fractures [30]. In fact, high fertility is encouraged by society and government health policy. Like abortion, female permanent sterilization is permitted under only very restricted circumstances and both potential parents must agree [31]. Contraceptives can have an impact on better spacing between children, better child care, improvement of children's health and preservation of the mother's health [32]. Yet, while most Islamic scholars do not expressly forbid contraception, there is no effective family planning programme supported directly by the Saudi Arabian government.

Because of high fertility and the inaccessibility of contraception, it is the norm in Saudi Arabian society that women continue giving birth late into their reproductive life, which increases the risk of having children with congenital and genetic abnormalities 
such as Down syndrome. There is a relation between Down syndrome and advanced maternal age or increased maternal parity. Thus, the incidence of the Down syndrome in a 9-year period study in Riyadh was 1.8 per 1000 live births [33]. In comparison, the actual live birth prevalence of Down syndrome during the same period in Sweden was 1.3 per $1000[34,35]$.

Male polygamy is another issue for women in Saudi Arabian culture. In Islam polygamy is neither mandatory, nor encouraged, but is permitted [36]. It is obligatory, however, to treat one's wives justly; this applies to housing, food, clothing, kind treatment, etc., for which the husband is fully responsible. All wives have the same status and are entitled to identical rights and claims over their husband [37]. However, polygamy can have negative impacts on the family's physical and mental health. Wives in polygamous marriages experience higher levels of psychological distress and more problems in family functioning, marital relationship and life satisfaction than monogamous marriages, while children in polygamous families have a higher rate of school conflicts and lower school achievement compared with children from monogamous families [38-40].

\section{Other social issues}

Local interpretations of Islamic law affect women's legal and social status in Saudi Arabia. For example, women in Saudi Arabia are forbidden to drive. Local custom is that male relatives drive females to their segregated schools or hospitals and collect them later on. This makes it hard for women to accept job opportunities in locations far from their families and homes. Consequently, non-Saudi Arabian female health workers cannot easily be replaced with Saudi Arabian women [14].
In the past, Saudi Arabian women were only named, and not pictured, on family identity (ID) cards which identify them as dependants of their husbands or fathers. This means that women's rights can be abused by their male guardians. For instance, in banks, courts and hospitals, with her face covered and without a photo-ID, the woman's identity cannot be confirmed. If a wife delivers, the newborn could be registered under another female's name especially if the Saudi Arabian father has more than one wife. Thus birth, marriage and death records are not reliable [9]. Recently, after a long debate with religious scholars about the permissibility of photographs of the female face, the government has allowed photo-ID cards to be issued to women. Nevertheless, as the male guardian's consent is obligatory, many Saudi Arabian females are still unable to obtain an individual ID [9].

\section{Discussion}

The distribution of power and resources in society is a key issue for public health policy and practice [41]. The World Health Organization has stated that gender inequity is not only a threat to economic development but also to population health, including that of future generations [42]. Gender inequity in health still exists even in developed countries of the world. For example, women in the United Kingdom report more problems with access to diabetes care than men [43]. Canadian women experience higher levels of distress (depression, anxiety, poor quality of life) than men after myocardial infarction [44]. Swedish women earn 10\%-20\% less than men at the same occupational level and with the same level of educational achievement; this has public health implications, as $90 \%$ of Swedish single parents of children below school aged 1-6 years are women [45]. In the United States of America female gender is associated with lower annual incomes amonggeneral practitioners [46], anaesthetists [47] and psychiatrists [48].

The traditional Arab family affects women's health in multiple ways. Finances are strictly the man's obligation. Young women are assigned the toughest household tasks. Marriage and motherhood are highly valued, but the pressure to produce sons is strong [49]. Women can be victims of "honour crimes" [50]. Poor relationships with fathers and history of abuse during adolescence can lead to depressive symptoms in girls [51]. There is an inverse relationship between the number of children a woman has and her education, income and age at marriage [52]. Education and employment status are good predictors of birth spacing preference and the health of mothers and children. The highest proportion of women with birth intervals $<3$ years are reported from the Middle East (in Jordan, Yemen and Saudi Arabia) $[53,54]$. Consanguinity — which is associated with women's lower education, lower socioeconomic status, younger age at marriage and higher fertility rate - remains high in many Middle Eastern countries. The prevalence of consanguinity varies from $68.0 \%$ in rural areas of Egypt to $57.7 \%$ in Saudi Arabia, 58.1\% in southern Jordan, 50.5\% in United Arab Emirates, 40\%-47\% in Yemen, 54.4\% in Kuwait and $35.9 \%$ in Oman [55-63]. Literacy levels are low: for example, $68 \%$ of Yemeni females are illiterate [64]. For half of Qatari women, the husband decides whether contraception is used or not [55] and half of Saudi Arabian women have a short birth interval ( $<2$ years) because of the husband's wish [53].

Only the Islamic Republic of Iran, Saudi Arabia and Sudan apply Islamic law to all matters of jurisprudence. However, different religious leaders interpret Islamic religious texts differently, particularly regarding women's issues such as wife abuse [65] and abortion. Hessini believes that the arguments of some conservative religious leaders, who 
are all men, are still being used to legitimize patriarchal practices [22]. Hassan argues that "The Qur'anic description of marriage suggests closeness, mutuality, and equality, but tradition defines a husband as his wife's god in earthly form (despite the Qur'an prohibition against human deification as the one unpardonable sin), her gateway to heaven, and the arbiter of her final destiny" [66]. In other verses, the Quran has indicated indirectly the optimum birth interval by specifying a suggested time of 24 months for breastfeeding (Quran 2:233; 31:14; $46: 15)$ but there is a mistaken belief that family planning is anti-Islam [53]. Customs that were originally intended to protect women and even guarantee women's autonomy (polygamy, inheritance rights, purdah and veiling) have, according to Hassan [66], become instead instruments of oppression.

Social norms and conservative religious beliefs have a powerful effect on women's lives and health in Saudi
Arabian society. The Saudi Arabian government issues ID cards to women but only if her male guardian allows it [9]. The government does not forbid females to practice sport in public or in segregated private places but societal norms limit females' outdoor exercise [18]. The government has implemented a compulsory national premarital screening programme for common inherited haematological diseases. However, the purpose of the health programme is abused since the final result does not affect the validity of the marriage [23]. The same applies to female medical education, which is encouraged by the government, but can be socially unacceptable and can be an obstacle to women's marriage [19]. There is a $\mathrm{MOH}$ law that permits adult woman to sign consent for some invasive radiological procedures but it is not always applied by medical employees [25]. A Saudi Arabian woman cannot be admitted to hospital without her male guardian and is not allowed to give her own consent for an invasive medical procedure [25]. Saudi Arabian law requires a male relative's agreement before seeking work, education, travel or issuing an identity card or passport [9]. The high prevalence of obesity among Saudi Arabian females can be attributed to social restrictions that prevent women participating in exercise in schools or in public [18].

The major limitation of this review was the scarcity of recent data and information about gender inequity, particularly about health care in Saudi Arabia. Nevertheless, to our knowledge this review is the first attempt to explore this sensitive issue in this unique country. In general, there is little available research that addresses knowledge, attitudes and practices towards the health care of Saudi Arabian women and men. These may represent important areas for future research.

\section{References}

1. Vo DX, Park MJ. Racial/ethnic disparities and culturally competent health care among youth and young men. American journal of men's health, 2008, 2(2):192-205.

2. Climo J. Eldercare as 'woman's work' in poor countries. In: Johnson N, Climo J, eds., Special issue: aging and elder care in lesser developed countries. Thousand Oaks, California, Sage Publications, 2000.

3. Arendell T, Estes C. Older women in the post-Regan era. In Fee E, Krieger N, eds. Women's health, politics, and power. Amityville, New York, Baywood Publishing, 1994.

4. Brody E. Women in the middle and family help to older people. Gerontologist, 1981, 21:450-71.

5. Tones K, Green J. Health promotion: planning and strategies. London, Sage Publications, 2004:68.

6. Amartya $\mathrm{S}$. The many faces of gender inequality. New republic, 2001, 225(12):35-41.

7. Health indicators 2005-2006. Ministry of Health of Saudi Arabia [website] (http://www.moh.gov.sa/statistics/Stat_Bk1426/ indicators.htm, accessed 16 June 2009).

8. The world factbook. Saudi Arabia. Central Intelligence Agency [website] (https://www.cia.gov/library/publications/theworld-factbook/geos/sa.html, accessed 16 June 2009).

9. Vidyasagar G, Rea D. Saudi women doctors: gender and careers within Wahhabic Islam and a 'westernised' work culture. Women's studies international forum, 2004, 27 (3):261-80.

10. Graham A. Finding, retrieving and evaluating journal and webbased information for evidence-based optometry. Clinical \& experimental optometry, 2007, 90(4):244-9.
11. Al-Yousuf M, Akerele T, Al-Mazrou Y. Organization of the Saudi health system. Eastern Mediterranean health journal, 2002, 8(4-5):645-53.

12. Alnaif M. Physicians perception of health insurance in Saudi Arabia. Saudi medical journal, 2006, 27(5):693-9.

13. Official Statistik om hälso- och sjukvårdspersonal - antal legitimerade (2003) och arbetsmarknadsstatus (2002) [Official statisitics about licenced medical personnel 2002-2003]. [website] (www. socialstyrelsen.se/NR/rdonlyres/ACA314E4-6F5F-4A13-A5101F4CFC75BE70/2941/2004463.pdf, accessed 16 June 2009).

14. Boutayeb A, Serghini M. Health indicators and human development in the Arab region. International journal of health geographics, 2006, 28(5):61.

15. The Work of WHO in the Eastern Mediterranean Region. Annual Report of the Regional Director. Cairo, WHO Regional Office for the Eastern Mediterranean, 2007.1 January - 31 December 2006 (http://www.emro.who.int/rd/annualreports/2006/pdf/indicators_healthstatus.pdf, accessed 12 December 2009).

16. Core health indicators: Sweden. World Health Organization [website] (http://www.who.int/countries/swe/en/, accessed 16 June 2009).

17. Klass D, Goss R. The politics of grief and continuing bonds with the dead: the cases of Maoist China and Wahhabi Islam. Death studies, 2003, 27(9):787-811.

18. Al-Nozha MM et al. Obesity in Saudi Arabia. Saudi medical journal, 2005, 26(5):824-9.

19. Neovius M, Janson A, Rossner S. Prevalence of obesity in Sweden. Obesity reviews, 2006, 7(1):1-3. 
20. Al-Tamimi DM. Saudi women in academic medicine. Are they succeeding? Saudi medical journal, 2004, 25(11):1564-7.

21. El-Gilany A, Al-Wehady A. Job satisfaction of female Saud nurses. Eastern Mediterranean health journal, 2001 7(1-2):31-7.

22. Hessini L. Abortion and Islam: policies and practice in the Middle East and North Africa. Reproductive health matters, 2007, 15(29):75-84

23. Al-Suliman A. Prevalence of beta-thalassemia trait in premarita screening in Al-Hassa, Saudi Arabia. Annals of Saudi medicine, 2006, 26(1):14-6.

24. Al Hajjaj MS. Medical practice in Saudi Arabia: the medicolega aspect. Saudi medical journal, 1996, 17:1-4.

25. Abu Aisha H. Women in Saudi Arabia: do they have the right to give their own consent for medical procedures? Saudi medical journal, 1985, 6:74-5.

26. Milaat W, Florey C. Perinatal mortality in Jeddah, Saudi Arabia. International journal of epidemiology, 1992, 21(1):82-90.

27. Shawky S, Milaat W. Early teenage marriage and subsequent pregnancy outcome. Eastern Mediterranean health journal, 2000, 6(1):46-54.

28. Highlight on health in Sweden. World Health Organization Regional Office for Europe [website] (http://www.euro.who.int/ document/e62337.pdf, accessed 16 June 2009).

29. Alkuraya F, Kilani R. Attitude of Saudi families affected with hemoglobinopathies towards prenatal screening and abortion and the influence of religious ruling (Fatwa). Prenatal diagnosis, 2001, 21(6):448-51.

30. Sadat-Ali $\mathrm{M}$ et al. Bone mineral density among postmenopausal Saudi women. Saudi medical journal, 2004, 25(11):1623-5.

31. Al-Kassimi M. Cultural differences: practicing medicine in an Islamic country. Clinical medicine, 2003, 3(1):52-3.

32. Bella $\mathrm{H}$ et al. The effects of birth interval on intellectual development of Saudi school children in Eastern Saudi Arabia. Saudi medical journal, 2005, 26(5):741-5.

33. Niazi M et al. Down's syndrome in Saudi Arabia: incidence and cytogenetics. Human heredity, 1995, 45(2):65-9.

34. Hedov G, Wikblad K, Anneren G. First information and support provided to parents of children with Down syndrome in Sweden: clinical goals and parental experiences. Acta paediatrica, 2002, 91(12):1344-9.

35. Lindsten J et al. Incidence of Down's syndrome in Sweden during the years 1968-1977. Human genetics. Supplement, 1981, 2 (Suppl.): 195210.

36. Mernissi F. Women and Islam. A historical and theological enquiry. Trans. Lakeland MJ. Oxford, Blackwell Publishers, 1991.

37. Hashim I. Reconciling Islam and feminism. Gender and development, 1999, 7(1):7-14

38. Al-Krenawi A, Graham JR, Slonim-Nevo V. Mental health aspects of Arab-Israeli adolescents from polygamous versus monogamous families. Journal of social psychology, 2002, 142(4):446-60

39. Al-Krenawi A, Graham JR.A comparison of family functioning, life and marital satisfaction, and mental health of women in polygamous and monogamous marriages. International journal of social psychiatry, 2006, 52(1):5-17.

40. Al-Krenawi A, Lightman ES. Learning achievement, social adjustment, and family conflict among Bedouin-Arab children from polygamous and monogamous families. Journal of social psychology, 2000, 140(3):345-55.

41. Fritzell J. Incorporating gender inequality into income distribution research. International journal of social welfare, 1999, 8:56-66.

42. Saylor C. The circle of health: a health definition model. Holistic nursing practice, 2004, 22(2):97-115.

43. Hippisley-Cox J et al. Sex inequalities in access to care for patients with diabetes in primary care: questionnaire survey. British journal of general practice, 2006, 56(526):342-8.
44. Woodend AK, Devins GM. Gender of the care environment: influence on recovery in women with heart disease. Canadian journal of cardiovascular nursing, 2005, 15(3):21-31.

45. Wamala S, Agren G. Gender inequity and public health. Getting down to real issues. European journal of public health, 2002, 12(3):163-5

46. Wallace AE, Weeks WB. Differences in income between male and female primary care physicians. Journal of the American Medical Women's Association, 2002, 57(4):180-4.

47. Weeks WB, Wallace AE, Mackenzie TA. Gender differences in anesthesiologists' annual incomes. Anesthesiology, 2007, 106(4):806-11.

48. Weeks WB, Wallace AE. Gender differences in the annual income of psychiatrists. Psychiatric services (Washington, D.C.), 2007, 58(4):515-20.

49. Zurayk H et al. Women's health problems in the Arab World: A holistic policy perspective. International journal of gynaecology and obstetrics, 1997, 58:13-21.

50. Kulwicki AD. The practice of honor crimes: a glimpse of domestic violence in the Arab world. Issues in mental health nursing, 2002, 23(1):77-87.

51. Afifi M. Depression in adolescents: gender differences in Oman and Egypt. Eastern Mediterranean health journal, 2006, 12(1-2):61-71.

52. Abu Ahmed A, Tabenkin H, Steinmetz D. [Knowledge and attitudes among women in the Arab village regarding contraception and family planning and the reasons for having numerous children]. Harefuah, 2003, 142:822-5 [In Hebrew].

53. Rasheed P, Al-Dabal B. Birth interval: perceptions and practices among urban-based Saudi Arabian women. Eastern Mediterranean health journal, 2007, 13(4):881-92.

54. Setty-Venugopal V, Upadhyay UD. Actual versus preferred birth intervals. Birth spacing: three to five saves lives. Baltimore, Johns Hopkins Bloomberg School of Public Health, 2002 (Population Reports, Series L, No. 13).

55. Bener A, Hussain R. Consanguineous unions and child health in the State of Qatar. Paediatric and perinatal epidemiology, 2006, 20(5):372-8.

56. Mokhtar MM, Abdel-Fattah MM. Consanguinity and advanced maternal age as risk factors for reproductive losses in Alexandria, Egypt. European journal of epidemiology, 2001, 17:559-65.

57. El-Hazmi MAF et al. Consanguinity among the Saudi Arabian population. Journal of medical genetics, 1995, 32:623-6.

58. Sueyoshi S, Ohtsuka R. Effects of polygyny and consanguinity on high fertility in the rural Arab population in South Jordan. Journal of biosocial science, 2003, 35:513-26.

59. Bener A et al. Consanguinity and associated sociodemographic factors in the United Arab Emirates. Human heredity, 1996, 46:256-64.

60. Abdulrazzaq YM et al. A study of possible deleterious effects of consanguinity. Clinical genetics, 1997, 51:167-73.

61. Gunaid AA, Hummad NA, Tamim KA. Consanguineous marriage in the capital city Sana'a, Yemen. Journal of biosocial science, 2004, 36:111-21.

62. Al-Awadi SA et al. The effect of consanguineous marriages on reproductive wastage. Clinical genetics, 1986, 29:384-8.

63. Rajab A, Patton MA. A study of consanguinity in the Sultanate of Oman. Annals of human biology, 2000, 27:321-6.

64. Date J, Okita K. Gender and literacy: factors related to diagnostic delay and unsuccessful treatment of tuberculosis in the mountainous area of Yemen. International journal of tuberculosis and lung disease, 2005, 9(6):680-5.

65. Ammar NH. Wife battery in Islam: a comprehensive understanding of interpretations. Violence against women, 2007, 13(5):516-26.

66. Hassan R. Women in Islam: Qur'anic ideals versus Muslim realities. Planned parenthood challenges, 1995, (2):5-9. 